\title{
Detection of plasma interleukin-8 in atopic dermatitis
}

\author{
H Kimata, I Lindley
}

\begin{abstract}
Plasma interleukin-8 (IL-8) concentrations were measured in patients with atopic dermatitis. Plasma IL-8 was not detected in 25 controls $(0 / 25)$, in allergic rhinitis $(0 / 20)$, or in bronchial asthma during remission $(0 / 13)$, while low concentrations of IL-8 were detectable in a few patients with urticaria $(1 / 19)$, contact dermatitis (4/17), and bronchial asthma at the time of attack (6/16). In contrast, IL-8 was detectable in most cases of atopic dermatitis (41/52). Moreover, IL-8 concentrations were significantly higher in severe than in mild or moderate atopic dermatitis. IL-8 concentrations decreased as atopic dermatitis was improved by treatment, and IgE production in vitro was also decreased while serum IgE concentrations remained unchanged. IL-8 measurement may be a useful tool for the study of the pathogenesis and clinical course of atopic dermatitis.

(Arch Dis Child 1994; 70: 119-122)
\end{abstract}

Atopic dermatitis is a prevalent inflammatory skin disease characterised by chronic pruritus and increased serum IgE concentrations. Although the pathogenesis remains to be elucidated, it has been suggested that dysregulation of cytokines, that is decreased production of interferon gamma and increased production of interleukin (IL)-4 may play a part in atopic dermatitis. ${ }^{1}$ Moreover, concentrations of plasma tumour necrosis factor- $\alpha$ have been shown to be increased in atopic dermatitis. ${ }^{2}$

IL-8 was originally identified as a neutrophil chemotactic cytokine. ${ }^{3}$ However, it has recently been reported that plasma IL-8 is increased in normal humans after intravenous injection of endotoxins. ${ }^{4}$ Bronchial epithelial cells from symptomatic asthmatic patients, but not from normal donors, have been shown to produce IL- $8 .{ }^{5}$ We have found that IL- 8 selectively inhibits IL-4 induced IgE production in

Characteristics of subjects studied

\begin{tabular}{|c|c|c|c|c|}
\hline & $\begin{array}{l}\text { Age } \\
\text { (years) }\end{array}$ & $\begin{array}{l}\text { Sex } \\
(F / M)\end{array}$ & $\underset{(\mu g / l)}{\operatorname{Serum}} \operatorname{IgE}$ & $\begin{array}{l}\text { Eosinophils } \\
\left(\times 10^{9} n\right)\end{array}$ \\
\hline Controls & $2-12(6 \cdot 6)^{\star}$ & $13 / 12$ & $36-1267(302)^{\star}$ & $0.06-0.39(0.13)^{\star}$ \\
\hline Allergic rhinitis & $4-15(7 \cdot 3)$ & $13 / 7$ & $96-1709(566)$ & $0.09-0.63(0.33)$ \\
\hline Urticaria & $2-15(6.4)$ & $9 / 10$ & $62-998(866)$ & $0.10-0.75(0.39)$ \\
\hline Contact dermatitis & $3-14(5.9)$ & $8 / 9$ & $70-934(602)$ & $0.05-0.74(0.41)$ \\
\hline Bronchial asthma remission & $2-15(5 \cdot 7)$ & $7 / 6$ & $600-9386(4454)$ & $0.36-1.21(0.79)$ \\
\hline At attack & $2-14(6 \cdot 1)$ & $9 / 7$ & 694-9895 (4589) & $0.31-1.30(0.82)$ \\
\hline \multicolumn{5}{|l|}{ Atopic dermatitis } \\
\hline Mild & $1-14(5 \cdot 8)$ & $7 / 9$ & $134-12907$ (4954) & $0.39-1.92(0.73)$ \\
\hline Moderate & $1-13(5.5)$ & 9/9 & $310-16596(6050)$ & $0.41-2.39(0.82)$ \\
\hline Severe & $1-15(6 \cdot 1)$ & $10 / 9$ & $1010-19502(7843)$ & $0.44-2.78(0.99)$ \\
\hline
\end{tabular}

${ }^{\star}$ Mean. vitro. ${ }^{6}$ These results indicate that IL- 8 may be an important cytokine in inflammatory and allergic diseases, and we therefore measured plasma IL-8 concentrations in atopic dematitis as well as in various allergic diseases.

\section{Subjects and methods}

SUBJECTS

Blood samples were collected from 25 healthy controls and from subjects with various allergic diseases including 20 patients with allergic rhinitis, 19 with acute urticaria, 17 with contact dermatitis, 29 with bronchial asthma without atopic dermatitis, and 52 with atopic dermatitis. Patients with bronchial asthma were divided into two subgroups, one group (13 patients) in remission and the other group (16 patients) having an attack.

The patients with atopic dermatitis were divided into three subgroups depending upon the severity of the atopic dermatitis according to the Rajika's grading and by our skin scoring system, that is mild (16 patients, skin score $0-8$ ), moderate (18 patients, skin score 9-16), and severe (18 patients, skin score $17-24) .{ }^{78}$ The characteristics of these patients are shown in the table. None of the patients was febrile, had an infection, or was receiving systemic steroids, anti-inflammatory medication, antiallergic medications, or antihistamines at the time of sampling of blood (baseline). Informed consent was obtained from the patients' parents.

TREATMENT OF PATIENTS WITH SEVERE ATOPIC DERMATITIS

We have previously reported that a topically applied sodium cromoglycate solution with antiallergic medication was very effective in the treatment of atopic dermatitis. ${ }^{7}$ Therefore, we treated 10 patients with severe atopic dermatitis with topical sodium cromoglycate solution (Fisons) twice daily and with $1.5 \mathrm{mg} / \mathrm{kg} /$ day of oral antiallergic medication, oxatomide (Kyowa Hakko, Osaka, Japan). At baseline (before treatment) and after four weeks patients were checked to determine skin scores by clinicians who were blind to this study. They were also checked for plasma IL-8 concentration, serum IgE, and in vitro spontaneous IgE production at baseline and after four weeks of treatment.

PLASMA

Fresh plasma was obtained from all subjects for the assaying of IL-8, IL-1 $\beta$, and IL-6. Blood samples for plasma were collected in 
tubes containing EDTA, placed immediately on ice, and stored at $-20^{\circ} \mathrm{C}$ until required.

\section{CYTOKINE ASSAY}

Plasma IL-1 $\beta$ and IL-6 were measured by ELISA ( $R$ and D Systems, Minneapolis, $\mathrm{MN}){ }^{4}$ The limits of detection were $30 \mathrm{ng} / \mathrm{l}$ for IL-1 $\beta$, and $15 \mathrm{ng} / 1$ for IL-6. IL-8 was measured by enzyme linked immunosorbent assay (ELISA) using mouse monoclonal antibody to IL-8 and goat polyclonal anti-IL-8 antibody (Sandoz, Vienna, Austria) linked to alkaline phosphatase. These antibodies react with endothelial and monocyte derived IL-8 and had no measurable cross reactivity with high concentrations of other known cytokines or growth factors, as was previously reported. ${ }^{4}$ Moreover, the antiallergic medication, oxatomide, did not interfere with this assay. The limits of detection were $20 \mathrm{ng} / \mathrm{l}$ of IL-8.

\section{SERUM IgE DETERMINATION AND IN VITRO IgE PRODUCTION}

Serum IgE was measured by solid phase radioimmunoassay (Phadebas IgE Prist, Pharmacia). Spontaneous in vitro IgE production in patients with severe atopic dermatitis was determined as previously reported. ${ }^{9}$ Briefly, heparinised peripheral blood was drawn at baseline and after four weeks of treatment. Mononuclear cells were obtained by Ficoll-Hypaque density sedimentation and were cultured $\left(2 \times 10^{5} /\right.$ well $\left./ 0.2 \mathrm{ml}\right)$ in 96 well $\mathrm{U}$ bottomed microtitre plates (Costar, Cambridge, MA) in Roswell Park Memorial Institute (RPMI) 1640 medium supplemented with $10 \%$ fetal calf serum, $2 \mathrm{mM}$ glutamine, $50000 \mathrm{U} / \mathrm{l}$ penicillin, and $50 \mathrm{mg} / 1$ streptomycin. After 14 days of incubation, IgE production was determined by ELISA. ${ }^{9}$ Net IgE production was calculated by subtracting the values of $\operatorname{IgE}$ obtained in parallel cultures containing cycloheximide $(100 \mathrm{mg} / \mathrm{l}) .^{9}$

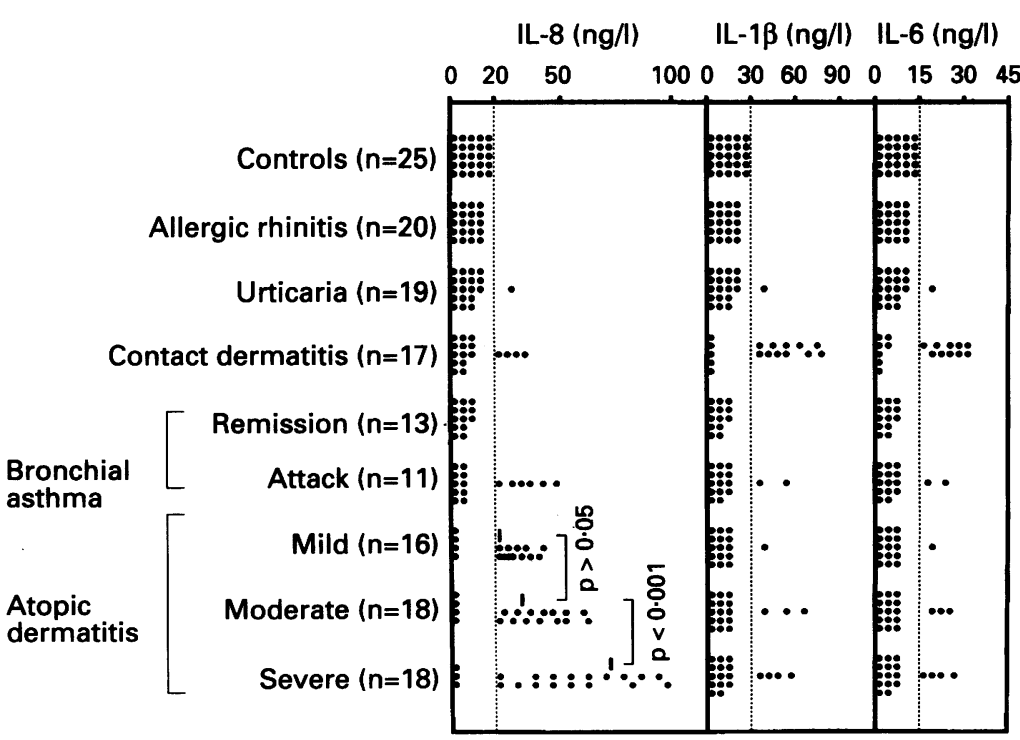

Figure 1 Plasma IL-8, IL-1B, and IL-6 concentrations in healthy controls and patients studied. Bars indicate the mean; dotted lines indicate lowest detectable limit for each cytokine and undetected samples were taken as zero when calculating mean.

\section{STATISTICAL ANALYSIS}

All results are reported as mean (SEM). Differences between the treatment groups were assessed by the two tailed $t$ test; a paired two tailed $t$ test was used for changes occurring in patients with atopic dermatitis from baseline and continuing to after four weeks of treatment.

\section{Results}

IL-8 CONCENTRATIONS IN PLASMA

As shown in fig $1, \mathrm{IL}-8$ was undetectable $(<20$ $\mathrm{ng} / \mathrm{l}$ ) in plasma from healthy controls and in patients with allergic rhinitis and bronchial asthma in remission. IL-8 was detectable in a few patients with urticaria, contact dermatitis, and bronchial asthma during an attack. In contrast, IL-8 was detected in most patients with mild (12/14), moderate (14/18), and severe atopic dermatitis (15/18). Moreover, IL-8 concentrations were significantly higher $(\mathrm{p}<0.001)$ in severe atopic dermatitis than in mild or moderate atopic dermatitis (fig 1 ).

\section{IL-1 $\beta$ AND IL-6 CONCENTRATIONS IN PLASMA}

As IL-8 may be detected as acute phase cytokines, we measured the other inflammatory cytokines, IL- $1 \beta$ and IL-6, and compared them with IL-8. IL-1 $\beta$ was detected in many patients with contact dermatitis (11/16) while it was barely detected in patients with mild $(1 / 16)$, moderate (3/18), and severe atopic dermatitis (4/18) (fig 1). Similarly, IL-6 was detected in many patients with contact dermatitis (10/17), while it was scarcely detected in patients with mild $(1 / 16)$, moderate $(3 / 18)$, and severe atopic dermatitis (4/18) (fig 1). These results indicate that an increase in IL-8 concentrations is unique to atopic dermatitis.

REDUCTION OF PLASMA IL-8 CONCENTRATIONS AND IN VITRO IgE PRODUCTION BY TREATMENT OF ATOPIC DERMATITIS

We have previously reported that topical sodium cromoglycate solution with oral antiallergic medication was very effective in the treatment of severe atopic dermatitis. ${ }^{7} \mathrm{We}$ thus treated patients with severe atopic dermatitis with topical sodium cromoglycate solution and an oral antiallergic medication, oxatomide. In 10 patients, the atopic dermatitis was significantly improved $(p<0.001)$ after four weeks of treatment as shown by the skin score (fig 2 ). Plasma IL-8 concentrations decreased significantly compared with baseline levels $(p<0.001)$ and spontaneous IgE production in vitro was also significantly decreased $(p<0.001$; fig 2). In contrast, serum IgE concentrations were unchanged ( $p>0.05$; fig 2 ). The blood eosinophil count was also unaffected $(\mathrm{p}>0.05)\left(0.99 \times 10^{9} / 1\right.$ at baseline $v$ $0.96 \times 10^{9} /$ after four weeks). The decreased IL-8 concentrations were not an artifact by sodium cromoglycate and oxatomide. After one week of treatment, atopic dermatitis had not improved remarkably. At that time, there 


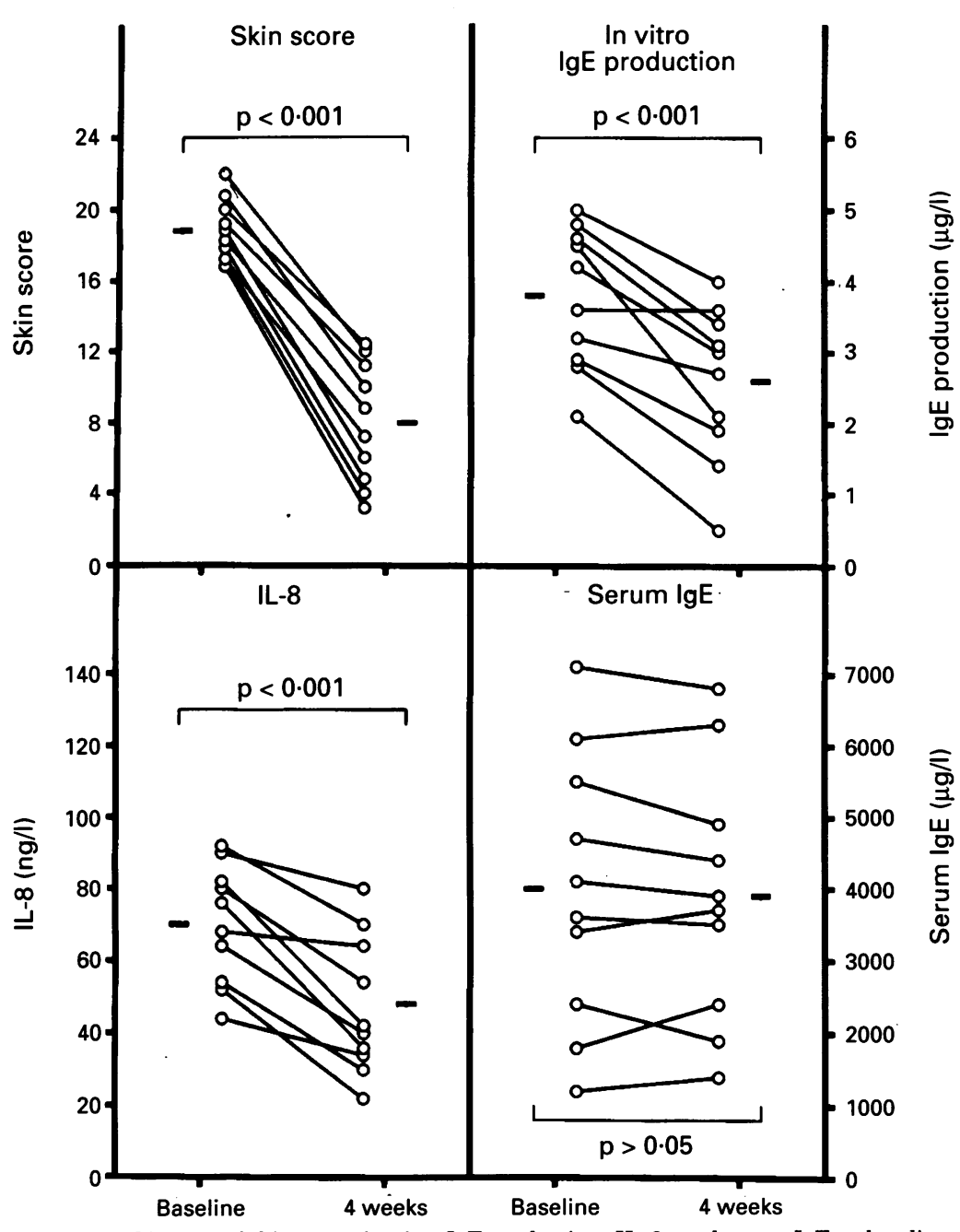

Figure 2 Changes of skin score, in vitro IgE production, IL-8, and serum IgE at baseline (before treatment) and four weeks after treatment. Bars indicate the mean. were no significant differences $(p>0.05)$ of mean skin score $(19.0$ at baseline $v 18.3$ after one week), of mean IL-8 concentrations $(70 \cdot 2$ $\mathrm{ng} / \mathrm{l}$ at baseline $v 68.7 \mathrm{ng} / \mathrm{l}$ after one week) or of mean IgE production in vitro $(3.8 \mu \mathrm{g} / \mathrm{l}$ at baseline $v 3.6 \mu \mathrm{g} / \mathrm{l}$ after one week). However, we have found that after eight weeks of treating of patients with severe atopic dermatitis by sodium cromoglycate solution and oxatomide, there was a significant $(p<0.001)$ reduction of mean serum IgE concentrations $(4020 \mu \mathrm{g} / \mathrm{l}$ at baseline $v 1985 \mu \mathrm{g} / \mathrm{l}$ at eight weeks of treatment).

As plasma IL-8 concentrations may be raised in acute phase responses, ${ }^{410}$ the increase of IL-8 in atopic dermatitis may simply reflect non-specific inflammation. Thus we measured IL-8 concentrations in patients with fever $\left(>38.5^{\circ} \mathrm{C}\right)$ caused by upper respiratory infection. Among 10 patients, IL-1 $\beta$ and IL-6 were detectable in eight and seven patients, respectively. The ranges of IL-1 $\beta$ and IL-6 were $36-53 \mathrm{ng} / \mathrm{l}$ (mean $37 \cdot 1 \mathrm{ng} / \mathrm{l}$ ) and 18-31 $\mathrm{ng} / \mathrm{l}$ (mean $17 \cdot 8 \mathrm{ng} / \mathrm{l})$, respectively. In contrast, IL-8 was detected in only one patient (mean $21 \mathrm{ng} / \mathrm{l})$.

\section{Discussion}

We have demonstrated that plasma IL-8 concentrations were raised in most patients with atopic dermatitis but they were barely detectable in healthy controls or in patients with other allergic diseases including allergic rhinitis, urticaria, or bronchial asthma in remission.

It is possible that the increase of plasma IL-8 in atopic dermatitis may simply reflect non-specific inflammation as plasma IL-8 concentrations may be raised in acute phase responses. ${ }^{4}$ However, this is unlikely for the following reasons. First, in contrast to atopic dermatitis, plasma IL-8 concentrations were undetectable or low in patients with contact dermatitis, which is a typical inflammation of the skin. Second, the inflammatory cytokines, IL- $1 \beta$ and IL- 6 , were undetectable or low in patients with atopic dermatitis. On the other hand, plasma concentrations of IL-1 $\beta$ and IL-6 were high in patients with contact dermatitis. Third, plasma IL-8 concentrations were not raised in patients with fever $\left(>38.5^{\circ} \mathrm{C}\right)$ caused by upper respiratory infection. Taken together these results may indicate that raised IL-8 concentrations are not due to non-specific inflammation, but that they are unique to atopic dermatitis.

It should be mentioned that IL- 8 was detectable in six out of 16 patients with bronchial asthma at the time of attack. This is in accordance with the report that alveolar macrophages from asthmatic patients secrete IL- 8 by anti-IgE. ${ }^{11}$ Moreover, the IL- 8 gene was expressed in a pulmonary epithelial cell line and in epithelial cells from symptomatic asthmatic patients secreting $\mathrm{IL}-8 .^{512}$ It is possible that alveolar macrophages and pulmonary epithelial cells are activated at the time of an asthmatic attack and secrete IL-8 that is detected in the blood.

We have also found that plasma IL-8 concentrations were significantly higher in severe than in mild or moderate atopic dermatitis. Moreover, when atopic dermatitis was improved by treatment, plasma IL- 8 concentrations decreased, as did spontaneous in vitro IgE production, but in contrast, serum IgE concentrations did not change during the treatment. It is not surprising that serum IgE concentrations did not decrease during the treatment. It has been reported that interferon gamma treatment of patients with atopic dermatitis improved the clinical severity of atopic dermatitis and decreased spontaneous in vitro production of $\operatorname{IgE}$ by the patients' mononuclear cells while there was no concomitant reduction of serum IgE concentrations. ${ }^{13}$ It is possible that a longer term of treatment may be required to reduce ongoing in vivo IgE production while short term treatment reduces in vitro IgE production. Indeed, we have found that after eight weeks of treating of patients with severe atopic dermatitis by sodium cromoglycate solution and oxatomide, there was a significant reduction of serum $\operatorname{IgE}$ concentrations. These results indicate that a change of in vitro IgE production occurs earlier than that of serum IgE concentrations. Taken together, measurements of plasma IL-8 concentrations and in vitro IgE production may provide a valuable tool for studying the clinical course of atopic dermatitis. 
The exact role of IL-8 in atopic dermatitis remains to be elucidated. IL-8 may have a role in skin disorders as it has been reported to be produced by keratinocytes. ${ }^{14} \mathrm{We}$ have reported that IL-8 selectively inhibits IgE production in vitro by directly affecting IgE producing $B$ cells. ${ }^{9}$ Moreover, histamine release from basophils is either inhibited or induced by IL-8 depending upon the experimental conditions. ${ }^{1516}$ It is tempting to speculate that IL-8 has an important role in allergic responses at local sites of the atopic dermatitis. Further analysis of the significance of raised IL-8 concentrations may be important for studying the pathogenesis of atopic dermatitis.

We wish to thank Dr P Peichl for the production of, and $M$ Ceska for the purification of the anti-IL-8 mAb, and $E$ Wasserbauer for the purification of IL-8.

1 Rousset F, Robert J, Andary M, et al. Shifts in interleukin-4 and interferon- $\gamma$ production by $T$ cells of patients with elevated serum IgE levels and the modulatory effects of these lymphokines on spontaneous IgE synthesis. $\mathcal{F}$ Allergy Clin Immunol 1991; 87: 58-69.

2 Sumimoto $\mathrm{S}$, Kawai $M$, Kasajima $\mathrm{Y}$, Hamamoto $\mathrm{T}$ Increased plasma tumour necrosis factor- $\alpha$ concentration increased plasma tumour necrosis factor- $\alpha$ concentr

3 Lindley I, Aschauer H, Seifert J-M, et al. Synthesis and expression in Escherichia coli of the gene encoding monocyte-derived neutrophil-activating factor: biological equivalence between natural and recombinant neutrophilactivating factor. Proc Natl Acad Sci USA 1988; 85: 9199-203.

4 Martich GD, Danner RL, Ceska M, Sufferdini AF. Detection of interleukin 8 and tumor necrosis factor in normal humans after intravenous endotoxin: the effect of antiinflammatory agents. $\mathcal{F}$ Exp Med 1991; 173: 1021-4.
5 Marini M, Vittori E, Hollemborg J, Mattoli S. Expression of the potent inflammatory cytokines, granulocytemacrophage-colony-stimulating factor and interleukin-6 and interleukin-8, in bronchial epithelial cells of patients with asthma. F Allergy Clin Immunol 1992; 89: 1001-9.

6 Kimata H, Yoshida A, Ishioka C, Lindley I, Mikawa H. Interleukin 8 selectively inhibits IgE production induced by interleukin 4 in human B cells. $\mathcal{F}$ Exp Med 1992; 176: by interleuki

7 Kimata H, Igarashi M. Topical cromolyn (disodium cromoglycate) solution in the treatment of young children with atopic dermatitis. Clin Exp Allergy 1990; 20: 281-3.

8 Rajika G, Langeland T. Grading the severity of atopic dermatitis. Acta Derm Venerol (Stockh) 1989; suppl 144 13-4

9 Kimata H, Yoshida A, Ishioka C, Mikawa H. Effect of human erythropoietin on human IgE production. Clin Exp Immunol 1991; 83: 483-7.

10 Negussie Y, Remick DG, De Forge LE, Kunkel SL, Eynon A, Griffin GE. Detection of plasma tumor necrosis factor, interleukin 6 , and 8 during the Jarisch-Herxheimer reacinterleukin 6, and 8 during the Jarisch-Herxheimer reac-

11 Gosset $\mathrm{P}$, Tonnel $\mathrm{AB}$, Joseph $\mathrm{M}$, et al. Secretion of a chemotactic factor for neutrophils and eosinophils by alveolar macrophages from asthmatic patients. $\mathcal{f}$ Allergy Clin Immunol 1984; 74: 827-34.

12 Standiford TJ, Kunkel SL, Basha MA, et al. Interleukin-8 gene expression by a pulmonary epithelial cell line. A model for cytokine networks in the lung. $\mathcal{f}$ Clin Invest 1990; 86: 1945-53.

13 Boguniewicz M, Jaffe HS, Izu A, et al. Recombinant gamma interferon in treatment of patients with atopic dermatitis and elevated IgE levels. Am 7 Med 1990; 88: 365-70.

14 Oppenheim JJ, Zacharide COC, Mukaida N, Matsushima K. Properties of the novel proinflammatory supergene 'intercrine' cytokine family. Annu Rev Immunol 1991; 9: 'intercrin'

15 Kuna P, Reddigari SR, Kornfeld D, Kaplan AP. IL-8 inhibits histamine release from human basophils induced by histamine-releasing factors, connective tissue activating peptide III, and IL-3. F Immunol 1991; 147: 1920-4

16 Dahinden CA, Kurimoto Y, De Weck AL, Lindley I Dewald B, Baggiolini M. The neutrophil-activating peptide NAF/NAP-1 induces histamine and leukotriene release by interleukin 3-primed basophils. $\mathcal{F}$ Exp Med 1989; 170: 1787-92. 